\title{
Protective Role of Melatonin and Taurine Against Carbamazepine-induced Toxicity in Freshly Isolated Rat Hepatocytes
}

\author{
Rol Protector de la Melatonina y Taurina contra la Toxicidad \\ Inducida por la Carbamazepina en Hepatocitos de Rata Recién Aislados
}

Mohammad Ali Eghbal ${ }^{*, * *}$; Shohreh Taziki, ${ }^{*, * * * * *}$ \& Mohammad Reza Sattari*****

EGHBAL, M. A.; TAZIKI, S. \& SATTARI, M. R. Protective role of melatonin and taurine against carbamazepine-induced toxicity in freshly isolated rat hepatocytes. Int. J. Morphol., 31(3):1081-1089, 2013.

SUMMARY: Carbamazepine is widely used in a broad spectrum of psychiatric and neurological disorders. Idiosyncratic hepatotoxicity is a well-known adverse reaction associated with carbamazepine. Hepatotoxicity is rare, but a real concern when initiating therapy. It was found that oxidative stress is a potential mechanism for carbamazepine-induced hepatotoxicity. Present study evaluated the hepato protective role of taurine and melatonin against carbamazepine-induced hepatotoxicity. Hepatocytes were prepared by the method of collagenase enzyme perfusion via portal vein. Cells were treated with $400 \mu \mathrm{M}$ carbamazepine, $1 \mathrm{mM}$ taurine, and $1 \mathrm{mM}$ melatonin. Cell death, reactive oxygen species formation, lipid peroxidation, and mitochondrial membrane depolarization were assessed as toxicity markers and the effects of taurine and melatonin administration on them were investigated. Our results showed that carbamazepine induced oxidative stress; increased ROS formation and lipid peroxidation products and also decreased mitochondrial membrane potential $\left(\Delta \Psi_{\mathrm{m}}\right)$. Carbamazepine caused a decrease in cellular glutathione content and an elevation in oxidized glutathione levels. Our investigation showed that preincubation of hepatocytes with taurine $(1 \mathrm{mM})$ could alleviate oxidative damages induced by carbamazepine; melatonin was also a good antioxidant to protect hepatocytes against cytotoxicity induced by carbamazepine. It may be concluded that taurine and melatonin are effective antioxidants to prevent carbamazepine-induced hepatotoxicity. Following our findings, further studies are suggested on the antioxidant effects of taurine and melatonin in patients receiving carbamazepine.

KEY WORDS: Carbamazepine; Hepatotoxicity; Oxidative stress; Taurine; Melatonin.

\section{INTRODUCTION}

Carbamazepine, one of the aromatic antiepileptic drugs, has been extensively used for treatment of psychiatric and neurological disorders. It was previously reported that aromatic antiepileptic drugs are potentially hepatotoxic. Hepatotoxicity associated with carbamazepine is rare but considerable. A transient increase of liver enzymes occured in $25-61 \%$ of patients administered carbamazepine (Ahmed \& Siddiqi, 2006; Forbes et al., 1992). The so-called hepatotoxicity progresses usually during the first six weeks after the onset of treatment (Santos et al., 2008a). In some investigations, it has been shown that reactive metabolites of carbamazepine could be involved in carbamazepineinduced hepatotoxicity. It is assumed that the accumulation of the arene oxide metabolites could be the responsible mechanism for the cellular damage caused by this drug (Bavdekar et al., 2004). Accumulation of arene oxide metabolite leads to direct mitochondrial toxicity, and also could result in immune response (Santos et al., 2008b).

Previous study showed that both the mitochondrial dysfunction and the oxidative stress caused by the metabolites of carbamazepine-induced hepatotoxicity (Santos et al., 2008a). To prevent carbamazepine-induced toxicity, no particular protective agents have been reported.Taurine is an essential amino acid containing a sulfonic acid group with several physiological roles. Taurine is a potent antioxidant and is able to scavenge reactive oxygen species (ROS), attenuate lipid peroxidation and stabilize biomembranes (Nandhini et al., 2005; Schaffer et al., 2009). There are many reports on taurine's protective effects against hepatotoxicities induced by different chemicals such as acetaminophen, carbon tetrachloride and retinol (Gaull et

\footnotetext{
* Drug Applied Research Center, Tabriz University of Medical Sciences, Tabriz, Iran.

** Department of Pharmacology \& Toxicology, Faculty of Pharmacy, Tabriz University of Medical Sciences, Tabriz, Iran.

${ }^{* * * *}$ Students' Research Committee, Faculty of pharmacy, Tabriz University of Medical Sciences, Tabriz, Iran.

*****Neurosciences Research Centre, Tabriz University of Medical Sciences, Tabriz, Iran.
} 
al., 1985; Nakashima et al., 1982; Waters et al., 2001). Melatonin is a hormone found naturally in the body. Previous studies demonstrated that melatonin has protective effect against oxidative damages caused by free radical species in cells or tissues (Hong et al., 2009). It efficiently scavenges the hydroxyl radical and possibly the peroxyl radical (Parmar et al., 2002). The hepatoprotective effect of melatonin against non-alcoholic fatty liver has been demonstrated in vivo (Pan et al., 2006). Based on our medical article databases, there are few studies on the hepato-protective role of antioxidants against carbamazepine-induced hepatotoxicity. In the present study, we investigated the protective roles of taurine and melatonin against cytotoxicity induced by carbamazepine towards freshly isolated rat hepatocytes. Cell death, ROS formation, lipid peroxidation and mitochondrial damage were considered as toxicity markers and the effects of taurine and melatonin on them were studied. Furthermore, the levels of cellular reduced and oxidized glutathione were measured to evaluate the ability of taurine and melatonin in preventing carbamazepine induced hepatotoxicity.

\section{MATERIAL AND METHOD}

Collagenase, carbamazepine and melatonin were purchased from Sigma Aldrich Chemical Co. (St. Louis, USA). Taurine, 4-2-hydroxyethyl-1-piperazineethanesulfonic acid (HEPES), triethanolamine, oxidized glutathione (GSSG), and 2-vinyl pyridine were obtained from Acros (New Jersey, USA). Other reagents were obtained from Merck Chemical Co. (Darmstadt, Germany). Taurine was prepared in water and melatonin and carbamazepine were dissolved in methanol. The amount of solvents in media was less than $20 \mu \mathrm{l} / 10 \mathrm{ml}$. The solvents have no effects on toxin or antioxidants effects.

Male Sprague-Dawley rats (250-300 g) were housed in plastic cages with $12 \mathrm{~h}$ light photoperiod and an environmental temperature of $21-23^{\circ} \mathrm{C}$ with a $50-60 \%$ relative humidity. They were obtained from the animal research center of Tabrize University of Medical Science.Animals were fed a standard chow diet and water ad libitum. The animals were handled and used according the animal handling protocol that approved by a local ethic committee in Tabriz University of medical sciences, Tabriz, Iran.

We isolated the hepatocytes from rat livers using collagenase perfusion technique which has been described in details before by Eghbal et al. (2004). First, through the portal vein, the liver parenchyma was perfused with different buffer solutions. So, the collagenase enzyme in buffer solution destructed the liver tissue and lead to easily isolation of hepatocytes during the next steps (Eghbal et al.). Isolated hepatocytes $\left(10 \mathrm{ml}, 10^{6}\right.$ cells $\left./ 1 \mathrm{ml}\right)$ were suspended in KrebsHenseleit buffer $(\mathrm{PH}=7.4)$ containing $12.5 \mathrm{mM}$ HEPES in continuously rotating $50 \mathrm{ml}$ rounded bottomed flasks at $37^{\circ} \mathrm{C}$ water bath under an atmosphere of carbogen gas $\left(95 \% \mathrm{O}_{2}\right.$ and $5 \% \mathrm{CO}_{2}$ ). Only the cells with viability of over the $85 \%$ were used. According to another study, carbamazepine as a parent compound was not able to induced oxidative stress. Therefore, activation of carbamazepine by the liver microsomal enzymes was a necessary step in the production of oxidative stress (Santos et al., 2008a). So, in this study, Cytochrome P450 enzymes were induced by Intra-peritoneal injection of Phenobarbital $(10 \mathrm{mg} / \mathrm{kg})$ to the rats for 3 days before the isolation of hepatocytes (Madan et al., 2003). Hepatocyte viability was determined microscopically by plasma membrane intactness as determined by trypan blue $(0.1 \%$ w/v) exclusion test (Moldeus et al., 1978). Hepatocyte viability was determined every 60 minutes for 180 minutes.

To determine the extent of ROS generated by carbamazepine, $1.6 \mu \mathrm{l}$ of 2-7-dichlorofluoresceinediacetate (DCFH-DA) was added to hepatocytes. DCFH-DA hydrolyzed to non-fluorescent DCFH in hepatocytes, DCFH reacted with ROS and became highly fluorescent. In 60,120,180 minutes 1 $\mathrm{ml}\left(10^{6}\right.$ cells $)$ of sample centrifuged at $3000 \mathrm{~g}$ for 1 minute, then the fluorescence of supernatant was detected fluorimetrically at excitation and emission wavelengths of 490 $\mathrm{nm}$ and $520 \mathrm{~nm}$ respectively (Anoush et al., 2009).

Hepatocytes lipid peroxidation was detected by measuring thiobarbituric acid reactive substance (TBARS) such as malondialdehyde (MDA) that formed during the decomposition of lipid hydroperoxides. $250 \mu \mathrm{l}$ of trichloro acetic acid (TCA, 70\% w/v) was added to $1 \mathrm{ml}\left(10^{6}\right.$ cells) of hepatocyte suspension and centrifuged at $3000 \mathrm{~g}$ for 15 minutes, then $1 \mathrm{ml}$ of thiobarbituric acid $(0.8 \% \mathrm{w} / \mathrm{v})$ was added to the supernatant and boiled for 20 minutes. The absorbance was measured at $532 \mathrm{~nm}$ using an UltrospecR 2000 spectrophotometer (Smith et al., 1982). TBARS formation was expressed as $\mathrm{mM}$ TBARS $10^{6}$ cells -1 .

To determine the Mitochondrial membrane potential (MMP); Rhodamine 123 (the fluorescent dye) accumulate in intact mitochondria by facilitated diffusion. When the MMP is altered by a toxin, there is no facilitated diffusion and the amount of Rhodamine 123 in media is increased. Two $\mathrm{ml}$ samples of the cell suspension were taken every 60 minutes for 180 minutes and centrifused at $1000 \mathrm{~g}$ for 1 minute then the cell was suspended in $2 \mathrm{ml}$ of KrebsHenseleit buffer containing $1.5 \mu \mathrm{M}$ Rhodamine 123 and incubated at $37^{\circ} \mathrm{C}$ water bath. Then centrifuged at $3000 \mathrm{~g}$ for 1 minute and hepatocytes were separated. The amount 
of Rhodamine 123 in media was determined using a Jusco FP-750 fluorescence spectrophotometer at $490 \mathrm{~nm}$ excitation and 520nm emission wavelengths. The difference of capacity of mitochondria to uptake the Rhodamine 123 between control group and treated group was expressed as percentage of control (Eghbal et al.; Heidari et al., 2012).

The hepatocyte glutathione (GSH) content was determined by the method of Elman (Riener et al., 2002). A 1 $\mathrm{ml}$ aliquot of cell suspension $\left(10^{6}\right.$ cells $\left./ \mathrm{ml}\right)$ was taken and treated with $2 \mathrm{ml}$ of trichloroacetic acid (5\% w/v) and centrifuged at $3000 \mathrm{~g}$ for 2 minutes. $0.5 \mathrm{ml}$ Elman reagent ( $0.0198 \%$ DTNB in $1 \%$ sodium citrate) and $3 \mathrm{ml}$ of phosphate buffer $(\mathrm{PH}=8.0)$ were added to supernatant. The color that developed was read at $412 \mathrm{~nm}$ using an Ultrospec $2000 \mathrm{R}$ spectrophotometer (Pharmacia Biotech). The samples were reduced with potassium borohydride $(\mathrm{KBH} 4)$ to prevent the auto oxidation of Glutathione during the experiment (Kleinman, W. A. \& Richie, 2000). The enzymatic recycling method was used to assess the hepatocyte oxidized glutathione (GSSG) level, where cellular GSH content was covalently bonded to 2-vinylpyridine at first. Then the excess 2-vinylpyridine was neutralized with thriethanolamine, and GSSG was reduced to GSH using the glutathione reductase enzyme and NADPH. The amount of GSH formed was measured as already described for GSH using the Elman reagent $(0.0198 \%$ DTNB in $1 \%$ sodium citrate). Absorbance was recorded at $412 \mathrm{~nm}$ after 60 , 120 and 180 minutes (Heidari et al.; Rahman et al., 2006). The amount of GSSG was determined from a standard curve.
Difference between control and treated groups was expressed as percentage of control. Results represent the Mean \pm SEM of at least three independent experiments. Statistical significance of difference between control and treatment groups was determined using one way analysis of variance (ANOVA) followed by a Tukey's post hoc test. The minimal level of significance was $(\mathrm{P}<0.05)$.

\section{RESULTS}

Carbamazepine toxicity in rat hepatocytes was concentration-dependent. As shown in Figure 1, incubation of hepatocytes with $400 \mu \mathrm{M}$ of carbamazepine led to the death of $50 \%$ of the cells in $2 \mathrm{~h}(\mathrm{LC} 50=400 \mu \mathrm{M})$. An optimum effective dose of taurine that provided appropriate protection was found $1 \mathrm{mM}$. Hepatocytes were treated with taurine 30 minutes before adding carbamazepine. It was found that taurine effectively prevented cell death induced by carbamazepine. Melatonin at the concentration of $1 \mathrm{mM}$ caused a significant decline in hepatocytes death $(\mathrm{p}<0.05)$.

As Figure 2 illustrates, carbamazepine $400 \mu \mathrm{M}$ caused an increase in ROS formation and pre-incubation of hepatocytes with $1 \mathrm{mMtaurine}$, decreasedROS formation conspicuously. Incubation of hepatocytes with $1 \mathrm{mM}$ melatonin, also decreased ROS formation significantly $(\mathrm{p}<0.05)$.

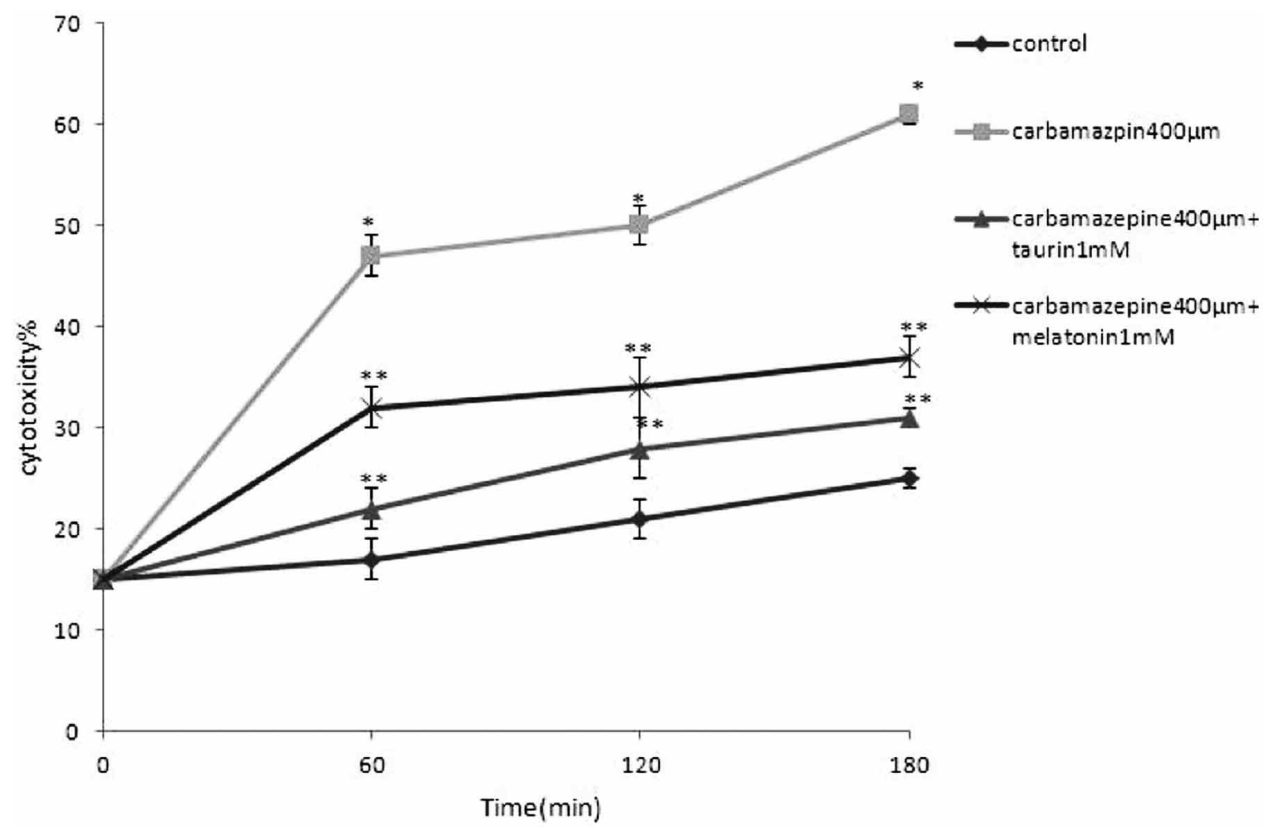

Fig. 1. Protective effect of taurine $(1 \mathrm{~mm})$ and melatonin $(1 \mathrm{~mm})$ against cell death induced by carbamazepine $(400 \mu \mathrm{m})$ in isolated rat hepatocytes. Results are mean \pm SEM of at least three different experiments.

*significantly different from control group $(\mathrm{p}<0.05)^{* *}$ significantly different from carbamazepine-treated hepatocytes $(\mathrm{P}<0.05)$ 
As shown in Figure 3, carbamazepine increased the amount of lipid peroxidation biomarkers meaningfully after 120 minutes. Pre-incubation of hepatocytes with $1 \mathrm{mMtaurine}$ prevented TBARS production significantly $(\mathrm{p}<0.05)$, and incubation of hepatocytes with $1 \mathrm{mM}$ melatonin, also reduced production of TBARS $(\mathrm{p}<0.05)$.
According to Figure 4, the effect of carbamazepine on the mitochondria as the energy-producing and key organelle of hepatocytes was evaluated. It was found that carbamazepine caused a reduction in MMP. It indicates the toxic effects of carbamazepine towards mitochondria. Taurine attenuated the reduction in MMP caused by carbamazepine. Also In the
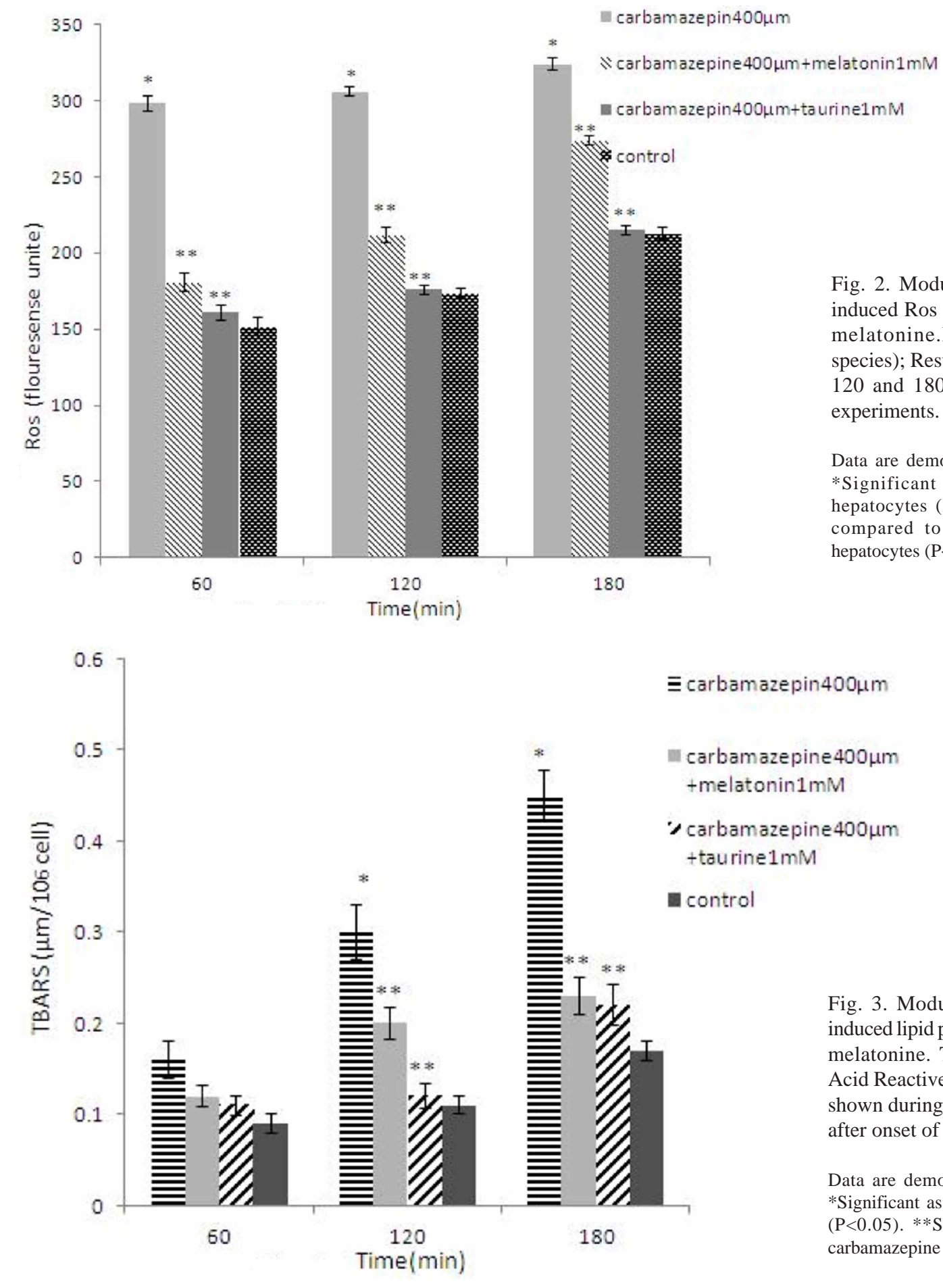

Fig. 2. Modulating carbamazepine induced Ros formation by taurine and melatonine.ROS (reactive oxygen species); Results are shown during 60, 120 and 180 minutes after onset of experiments.

Data are demonstrated as Means \pm SEM. * Significant as compared to control hepatocytes $(\mathrm{P}<0.05)$. **Significant as compared to carbamazepine -treated hepatocytes $(\mathrm{P}<0.05)$.

\section{0}

Fig. 3. Modulating carbamazepine induced lipid peroxidation bytaurine and melatonine. TBARS (ThioBarbituric Acid Reactive Substances). Results are shown during 60,120 and 180 minutes after onset of experiments.

Data are demonstrated as Means \pm SEM. *Significant as compared to control group $(\mathrm{P}<0.05)$. **Significant as compared to carbamazepine -treated group $(\mathrm{P}<0.05)$. 
presence of $1 \mathrm{mM}$ melatonin, the mitochondrial toxicity declined dramatically $(\mathrm{p}<0.05)$ (Fig. 4).

As illustrated in Figure 5, carbamazepine exposure significantly diminished GSH levels of hepatocytes, a result that is in line with the results of the tests of ROS formation and Lipid peroxidation. Glutathione contents of carbamazepine-exposed cells were notably increased in the melatonin- and/ortaurine-supplemented groups $(\mathrm{p}<0.05)$.
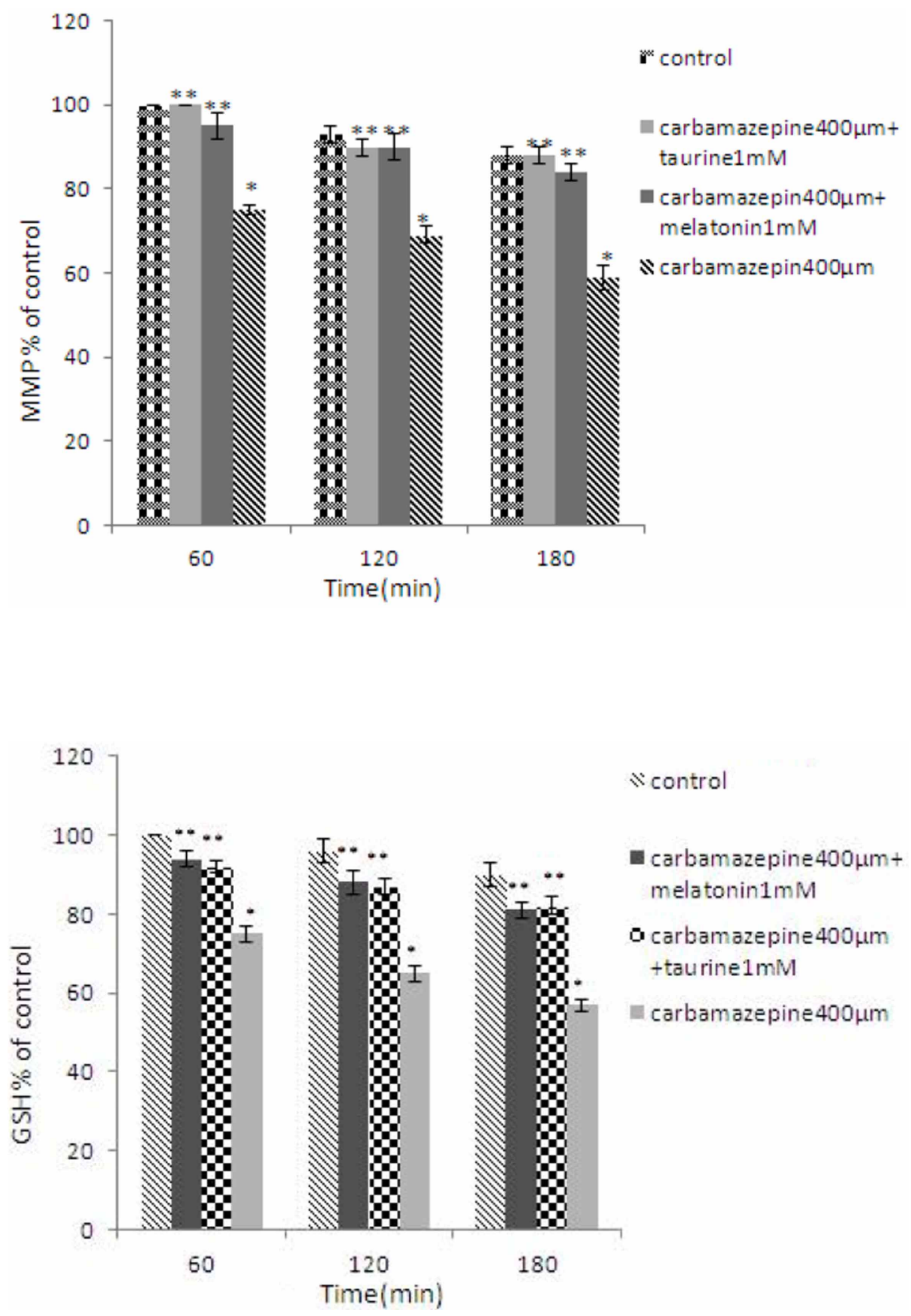

Fig. 4. Modulating carbamazepine -induced mitochondrial membrane potential toxicity by taurineandmelatonine. MMP (Mitochondrial Membrane Potential); Results are shown during 60, 120 and 180 minutes after onset of experiments.

Data are demonstrated as Means \pm SEM.

*Significant as compared to control group $(\mathrm{P}<0.05)$. ** Significant as compared to carbamazepine -treated hepatocytes $(\mathrm{P}<0.05)$.

Fig. 5. Modulating carbamazepine decreased GSH levels by taurine and melatonine. GSH: Results are shown during 60, 120 and 180 minutes after onset of experiments.

Data are demonstrated as Means \pm SEM.

*Significant as compared to control group $(\mathrm{P}<0.05)$. ** Significant as compared to carbamazepine -treated hepatocytes $(\mathrm{P}<0.05)$. 


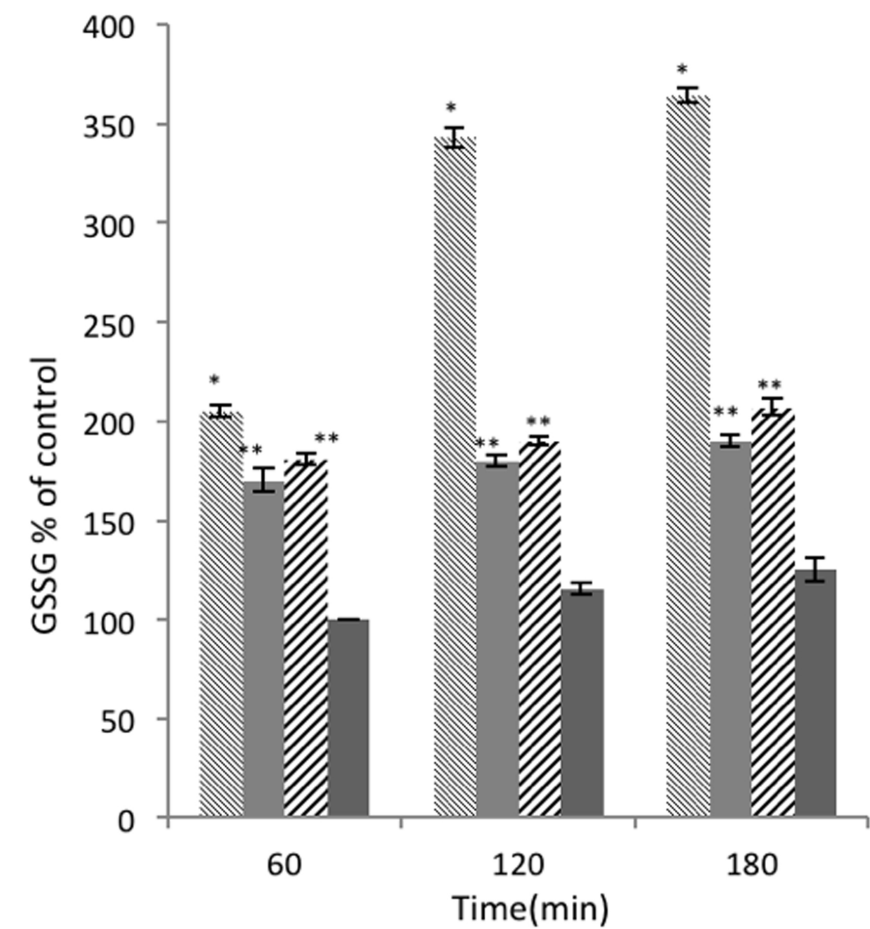

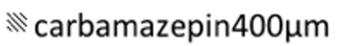

carbamazepine400 $\mu \mathrm{m}$ +taurine $1 \mathrm{mM}$

" carbamazepine $400 \mu \mathrm{m}$ + melatonin $1 \mathrm{mM}$

control

Fig. 6. modulating carbamazepine increased GSSG levels by taurine and melatonine. GSSG: Glutathione disulfide. Results are shown during 60, 120 and 180 minutes after onset of experiments.

Data are demonstrated as Means \pm SEM. * Significant as compared to control group $(\mathrm{P}<0.05)$. ** significant as compared to carbamazepine -treated hepatocytes $(\mathrm{P}<0.05)$.

\section{DISCUSSION}

In this study, we investigated oxidative stress biomarkers such as ROS formation, lipid peroxidation, MMP, and the levels of protein sulfhydryls in isolated rat hepatocytes in the absence or presence of an antioxidant. We established cytoprotectiv estrategies concerning the hepatotoxicity associated with carbamazepine therapy. The toxicity was investigated in hepatocytes induced by phenobarbital (CYP450 inducer), because of the probability that the intermediate areneoxides formed in biotransformation might be the causes of the toxicity (Bavdekar et al.; Kalapos, 2002; Madden et al., 1996; Shear \& Spielberg, 1988). The results of our study showed that oxidative stress was involved in hepatotoxicity induced by carbamazepine and its metabolites. This is in agreement with the previous findings (Santos et al., 2008a, 2008b; Aycicek \& Iscan, 2007). Exposure to carbamazepine dramatically increased ROS production, enhanced oxidative stress and induced cell death in hepatocytes. Reactive oxygen species may be involved in the progressive course of this hepatotoxicity. Therefore, we evaluated whether taurine, an endogenous antioxidant, could limit the extent of liver injury. In this study we found that the cell viability was improved upon taurine treatment. Pre-incubation of hepatocytes with taurine could significantly decrease ROS formation. Taurine is an amino acid with a sulfonic acid group, and probably reacts with reactive oxygen species;complex formation between sulfonic acid group ( $\mathrm{SO} 3$-) to free ion species has been reported (Trachtman et al., 1992). Hence, the reactive oxygen species formed during carbamazepine metabolism were scavenged by taurine, this may have had a role in its protective effects in carbamazepine cytotoxicity. Lipid peroxidation is usually one of the consequences of ROS formation and oxidative stress in biological systems (Benzie et al., 1996).

Taurine could protect hepatocytes from lipid peroxidation induced by carbamazepine after $2 \mathrm{~h}$ of incubation. The role of taurine in attenuating the lipid peroxidation induced by carbamazepine mightbe due to its effects in modulating the oxidative stress caused by this drug. It is believed that taurine's ability to stabilize cell membranes may be attributed to several events, one of them is prevention of lipid peroxidation (van Gelder, 1990). The effect of carbamazepine and its metabolite on the mitochondria as the energy-producing and key organelle of hepatocytes was evaluated. It was found that carbamazepine decreased MMP, that is in line with the previous finding demonstrating the mitochondrial toxicity induced by carbamazepine and its metabolites. It is noteworthy that mitochondrial dysfunction is generally accompanied by oxidative stress; a key regulator of mitochondria-mediated cell death in hepatocytes (Santos et al., 2008b). 
One of the pathways for disruption of mitochondrial function involves ROS formation and GSH oxidation. ROS formation and GSH depletion increases permeability transition pore (PTP) formation; PTP opening can also lead to the release of cytochrome $\mathrm{C}$, ultimately causing apoptotic cell death (Eghbal et al.). Our results showed that taurine attenuated the reduction in MMP caused by carbamazepine. This effect may be due to the ability of taurine in scavenging the reactive metabolites produced during carbamazepine metabolism. High concentrations of GSH are present in most living cells. It is believed that GSH is involved in responses to various oxidative stresses. GSH serves several vital functions, including detoxifying electrophiles, maintaining the essential thiol status of proteins, scavenging free radicals, modulating critical cellular processes such as DNA synthesis, and immune function. Severe oxidative stress may overcome the ability of the cell to reduce GSSG to GSH, leading to the accumulation of GSSG within the cytosol (Lu, 1999). In this study, carbamazepine decreased GSH and increased GSSG levels. Our results showed that taurine could prevent oxidation of glutathione. Taurine is a ROS scavenger and decreases the level of free radicals. Therefore, in the supplemented group with taurine, less GSH was oxidized to GSSG, and GSSG accumulation was prevented. With regard to melatonin, incubation of hepatocytes with the $1 \mathrm{mM}$ of melatonin decreased the death rate of hepatocytes significantly. Both ROS formation and TBARS production were reduced in the presence of melatonin. These findings confirm previous studies regarding the antioxidant effects of melatonin. Melatonin is an efficient scavenger of ROS which are abundantly produced in mitochondria (Parmar et al.). Hence, the reactive oxygen species formed during carbamazepine metabolism were scavenged by melatonin; this might have a role in its protective effects in carbamazepine cytotoxicity. A reduction in cellular glutathione by carbamazepine or its metabolite leaves hepatocytes defenseless against different stresses such as ROS formation. This may have a role in carbamazepine-induced hepatotoxicity. Melatonin can react with free radicals or reactive metabolites produced during carbamazepine metabolism, and prevent glutathione consumption in hepatocytes. Preventing the depletion of glutathione reservoirs could be another mechanism by which melatonin reduces the toxicity of carbamazepine or its reactive metabolites in hepatocytes. In vitro experiments showed that melatonin could prevent oxidative damage in mitochondria induced by t-butyl hydro peroxide. Previous findings documented that melatonin can stimulate complexes 1 and 4 activities. It was reported that ATP production elevated in the presence of melatonin (Martín et al., 2002). Therefore, we evaluated whether melatonin could prevent the decline of MMP induced by carbamazepine. Our data showed that melatonin supplementation could prevent the decrease of MMP. It might have occurred as a consequence of the ROS scavenging effect of melatonin (El Idrissi et al, 2003).

\section{CONCLUSION}

According to our study results, it could be concluded that taurine and melatonin are effective antioxidants in prevention of carbamazepine-induced hepatotoxicity. However, there was no statistically significant difference in hepatoprotective effects between melatonin and taurine. We recommend further clinical trial studies on the antioxidant effects of taurine and melatonin in patients receiving carbamazepine.

\section{ACKNOWLEDGMENT}

The authors are indebted to "Drug Applied Research Center" of Tabriz University of Medical Sciences for financial support of this study and providing technical facilities. The authors are thankful to the "students' research committee of Tabriz University of Medical Sciences, TabrizIran, for providing technical supports to the study. This article is written based on the results of thesis No.66, submitted to Tabriz University of Medical Sciences, Tabriz-Iran in fulfillment of the requirements of PhD Degree, of Dr. Shohreh Taziki.

EGHBAL, M. A.; TAZIKI, S. \& SATTARI, M. R. Rol protector de la melatonina y taurina contra la toxicidad inducida por la carbamazepina en hepatocitos de rata recién aislados. Int. J. Morphol., 31(3):1081-1089, 2013.

RESUMEN: La carbamazepina es ampliamente utilizada en un gran espectro de trastornos psiquiátricos y neurológicos. La hepatotoxicidad idiosincrásica es una conocida reacción adversa asociada con la carbamazepina. La hepatotoxicidad es rara, pero es una preocupación real al iniciar el tratamiento. Se ha reportado que el estrés oxidativo es un potencial mecanismo para la hepatotoxicidad inducida por carbamazepina. El presente estudio evaluó la función hepato-protectora de la taurina y melatonina contra la hepatotoxicidad inducida por carbamazepina. Los hepatocitos se prepararon por el método de perfusión de la enzima colagenasa a través de la vena porta. Las células fueron tratadas con $400 \mu \mathrm{M}$ de carbamazepina, $1 \mathrm{mM}$ de taurina, y $1 \mathrm{mM}$ de melatonina. La muerte celular, formación de especies reactivas de oxígeno (ERO), peroxidación de lípidos, y despolarización de la membrana mitocondrial fueron evaluadas como marcadores de toxicidad, junto con investigar los efectos de la taurina y melatonina administrada en ellos. Nuestros resultados mostraron estrés oxidativo inducido 
por carbamazepina, con aumento de las ERO, formación de productos de la peroxidación lipídica y disminución del potencial de membrana mitocondrial $\left(\Delta \Psi_{\mathrm{m}}\right)$. La carbamazepina causó una disminución en el contenido celular de glutatión y una elevación de los niveles de glutatión no-oxidado. Se observó que la preincubación de los hepatocitos con taurina $(1 \mathrm{mM})$ podría aliviar los daños oxidativos inducidos por carbamazepina; además la melatonina también fue un buen antioxidante para proteger a los hepatocitos. Se puede concluir que tanto la taurina y melatonina son antioxidantes eficaces para prevenir la hepatotoxicidad inducida por carbamazepina. Tras nuestros resultados, se sugiere estudiar los efectos antioxidantes de la taurina y melatonina en pacientes tratados con carbamazepina.

PALABRAS CLAVE: Carbamazepina; Hepatotoxicidad; Estrés oxidativo; Taurina; Melatonina.

\section{REFERENCES}

Ahmed, S. N. \& Siddiqi, Z. A. Antiepileptic drugs and liver disease. Seizure, 15(3):156-64, 2006.

Anoush, M.; Eghbal, M. A.; Fathiazad, F.; Hamzeiy, H. \& Kouzehkonani, N. S. The protective effects of garlic extract against acetaminophen-induced oxidative stress and glutathione depletion. Pak. J. Biol. Sci., 12(10):765-71, 2009.

Aycicek, A. \& Iscan, A. The effects of carbamazepine, valproic acid and phenobarbital on the oxidative and antioxidative balance in epileptic children. Eur. Neurol., 57(2):65-9, 2007.

Bavdekar, S. B.; Muranjan, M. N.; Gogtay, N. J.; Kantharia, V. \& Kshirsagar, N. A. Anticonvulsant hypersensitivity syndrome: lymphocyte toxicity assay for the confirmation of diagnosis and risk assessment. Ann. Pharmacother., 38(10):1648-50, 2004.

Benzie, I. F. Lipid peroxidation: a review of causes, consequences, measurement and dietary influences. Int. J. Food Sci. Nutr., 47(3):233-61, 1996.

Eghbal, M. A.; Pennefather, P. S. \& O'Brien, P. J. H2S cytotoxicity mechanism involves reactive oxygen species formation and mitochondrial depolarisation. Toxicology, 203(1-3):69-76, 2004.

El Idrissi, A.; Messing, J.; Scalia, J. \& Trenkner, E. Prevention of epileptic seizures by taurine. Adv. Exp. Med. Biol., 526:515$25,2003$.

Forbes, G. M.; Jeffrey, G. P.; Shilkin, K. B. \& Reed, W. D. Carbamazepine hepatotoxicity: another cause of the vanishing bile duct syndrome. Gastroenterology, 102(4 Pt.1):1385-8, 1992.

Gaull, G. E.; Pasantes-Morales, H. \& Wright, C. E. Taurine in human nutrition: overview. Prog. Clin. Biol. Res., 179:3-21, 1985.

Heidari, R.; Babaei, H. \& Eghbal, M. A. Ameliorative effects of taurine against methimazole-induced cytotoxicity in isolated rat hepatocytes. Sci. Pharm., 80(4):987-99, 2012.

Hong, R. T.; Xu, J. M. \& Mei, Q. Melatonin ameliorates experimental hepatic fibrosis induced by carbon tetrachloride in rats. World J. Gastroenterol., 15(12):1452-8, 2009.

Kalapos, M. P. Carbamazepine-provoked hepatotoxicity and possible aetiopathological role of glutathione in the events. Retrospective review of old data and call for new investigation. Adverse Drug React. Toxicol. Rev., 21(3):123-41, 2002.

Kleinman, W. A. \& Richie, J. P. Jr. Status of glutathione and other thiols and disulfides in human plasma. Biochem. Pharmacol., 60(1):19-29, 2000.

Lu, S. C. Regulation of hepatic glutathione synthesis: current concepts and controversies. FASEB J., 13(10):1169-83, 1999.

Madan, A.; Graham, R. A.; Carroll, K. M.; Mudra, D. R.; Burton, L. A.; Krueger, L. A.; et al. Effects of prototypical microsomal enzyme inducers on cytochrome $\mathrm{P} 450$ expression in cultured human hepatocytes. Drug Metab. Dispos., 31(4):421-31, 2003.

Madden, S.; Maggs, J. L. \& Park, B. K. Bioactivation of carbamazepine in the rat in vivo. Evidence for the formation of reactive arene oxide(s). Drug Metab. Dispos., 24(4):46979, 1996.

Martín, M.; Macías, M.; León, J.; Escames, G.; Khaldy, H. \& Acuña-Castroviejo, D. Melatonin increases the activity of the oxidative phosphorylation enzymes and the production of ATP in rat brain and liver mitochondria. Int. J. Biochem. Cell Biol., 34(4):348-57, 2002.

Moldeus, P.; Hogberg, J. \& Orrenius, S. Isolation and use of liver cells. Methods Enzymol., 52:60-71, 1978.

Nakashima, T.; Taniko, T. \& Kuriyama, K. Therapeutic effect of taurine administration on carbon tetrachloride-induced hepatic injury. Jpn. J. Pharmacol., 32(4):583-9, 1982.

Nandhini, A. T.; Thirunavukkarasu, V.; Ravichandran, M. K. \& Anuradha, C. V. Effect of taurine on biomarkers of oxidative stress in tissues of fructose-fed insulin-resistant rats. Singapore Med. J., 46(2):82-7, 2005.

Pan, M.; Song, Y. L.; Xu, J. M. \& Gan, H. Z. Melatonin ameliorates nonalcoholic fatty liver induced by high-fat diet in rats. $J$. Pineal Res., 41(1):79-84, 2006.

Parmar, P.; Limson, J.; Nyokong, T. \& Daya, S. Melatonin protects against copper-mediated free radical damage. J. Pineal Res., 
$32(4): 237-42,2002$.

Rahman, I.; Kode, A. \& Biswas, S. K. Assay for quantitative determination of glutathione and glutathione disulfide levels using enzymatic recycling method. Nat. Protoc., 1(6):315965, 2006.

Riener, C. K.; Kada, G. \& Gruber, H. J. Quick measurement of protein sulfhydryls with Ellman's reagent and with 4,4'dithiodipyridine. Anal. Bioanal. Chem., 373(4-5):266-76, 2002.

Santos, N. A.; Medina, W. S.; Martins, N. M.; Rodrigues, M. A.; Curti, C. \& Santos, A. C. Involvement of oxidative stress in the hepatotoxicity induced by aromatic antiepileptic drugs. Toxicol. In Vitro, 22(8):1820-4, 2008a.

Santos, N .A.; Medina, W. S.; Martins, N. M.; Mingatto, F. E.; Curti, C. \& Santos, A. C. Aromatic antiepileptic drugs and mitochondrial toxicity: effects on mitochondria isolated from rat liver. Toxicol. In Vitro, 22(5):1143-52, 2008 b.

Schaffer, S. W.; Azuma, J. \& Mozaffari, M. Role of antioxidant activity of taurine in diabetes. Can. J. Physiol. Pharmacol., 87(2):91-9, 2009.

Shear, N. H. \& Spielberg, S. P. Anticonvulsant hypersensitivity syndrome. In vitro assessment of risk. J. Clin. Invest., 82(6):1826-32, 1988.

Smith, M. T.; Thor, H.; Hartizell, P. \& Orrenius, S. The measurement of lipid peroxidation in isolated hepatocytes. Biochem. Pharmacol., 31(1):19-26, 1982.

Trachtman, H.; Del Pizzo, R.; Futterweit, S.; Levine, D.; Rao, P. S.; Valderrama, E.; et al. Taurine attenuates renal disease in chronic puromycin aminonucleoside nephropathy. Am. J. Physiol., 262(1 Pt. 2):F117-23, 1992.

van Gelder, N. M. Neuronal discharge hypersynchrony and the intracranial water balance in relation to glutamic acid and taurine redistribution: migraine and epilepsy. Prog. Clin. Biol. Res., 351:1-20, 1990.

Waters, E.; Wang, J. H.; Redmond, H. P.; Wu, Q. D.; Kay, E. \& Bouchier-Hayes, D. Role of taurine in preventing acetaminophen-induced hepatic injury in the rat. Am. J. Physiol. Gastrointest. Liver Physiol., 280(6):G1274-9., 2001.
Correspondence to: Mohammad Ali Eghbal

Department of Pharmacology \& Toxicology

Faculty of Pharmacy

Tabriz University of Medical Sciences

Tabriz

IRAN

Tel: +984113372250

Fax: +98411334 4798

Email: m.a.eghbal@hotmail.com

Received: 09-03-2013

Accepted: 09-06-2013 